ИСТОРИЯ ПРАВА

UDC 340.15

\title{
N. Kršljanin
}

\section{THE LAND REFORM OF THE 1830s IN SERBIA: THE IMPACT OF THE SHATTERING OF THE OTTOMAN PROPERTY SYSTEM ${ }^{1}$}

The paper concerns the process of weakening of the Ottoman property system in Serbia after the Serbian uprisings, particularly in the period of 1815-1830, its subsequent abolition by the Hatt-i humayun of 1830 and the introduction of a modern system of private property in the 1830s, culminating with the Restoration of lands Act in 1839. This reform, although beyond any doubt useful both for the economy and for the legal system of Serbia, was also accompanied by frequent abuse of the rights of peasants by rich (large) landowners, including the ruler of Serbia, Prince (Knjaz) Miloš himself. Such a course of action caused great displeasure in the general population, resulting in numerous peasant revolts (the most important being Đak's revolt of 1824 and Mileta's revolt of 1835), which, in turn, impacted the reform process again. The paper shows the legal consequences of the new concept of property rights, their impact upon the dominantly rural society of Serbia and the intricate interrelationship of the revolts and the reform process. Refs 62 .

Keywords: land reform, private property, abolishment of the Ottoman timar system, peasant revolts, legal history, Serbia, Miloš Obrenović.

\section{INTRODUCTION}

Serbia has been under Ottoman rule from 1459 until 1878: it has been a long and tumultuous period of serving foreign masters and living under foreign law. The entire 19th century presents a gradual process of liberation, of gaining first more and more autonomy, and finally independence. As Nedeljković ${ }^{2}$ has pointed out, the agrarian question and the yearning for economic liberation of private property has been at the root of practically all wars and uprisings in Serbia since the First Serbian uprising of 1804 all the way to the Balkan Wars of 1912 [1, p. 2]; it could be argued that the issue arose even earlier [2, p. 38-42], and Srdanović-Barać has called the process "agrarian revolution" [3]. Of course, pointing out this factor doesn't mean denying the national and political nature of these conflicts.

The focus and the scope of this article do not allow for a detailed exposition of the events of the uprisings, or, as Ranke called them, the Serbian Revolution [4]: they will be

Kršljanin Nina - PhD, assistant professor at the University of Belgrade Faculty of Law, Department of Legal History; nina.krsljanin@ius.bg.ac.rs

1 This article is a modified version of the paper presented at the conference Old and New Worlds: The Global Challenges of Rural History in Lisbon, 27-30 January 2016.

${ }^{2}$ Serbian names and terms are given in Serbian Latin spelling, while the usual English transcription is used for Turkish names and terminology.

(с) Санкт-Петербургский государственный университет, 2017 
mentioned only briefly. However, the period between the Second Serbian uprising and the Hatt-i sherif (Hatt-i humayun) that granted Serbia autonomy (1815-1830) deserves to be covered in more detail, since it shows the struggle for both political emancipation and agrarian reform.

\section{THE OTTOMAN PROPERTY SYSTEM AND THE SERBIAN UPRISINGS}

After the conquest of Serbia by the Ottoman Empire in the 15th century, the old system of land property (baština) was replaced by a completely different system of property. ${ }^{3}$ In it, the land belonged to God, or the Sultan as his regent on Earth, while the sipahi (horsemen in the army) only held parts of it (timar, zeamet, has) with the right to collect various tolls from the inhabitants ${ }^{4}$; they did not own the land and thus could not sell it or leave it to their heirs. ${ }^{5}$ At first, some of the Serbian nobility who swore fealty to the Sultan also became sipahi; but after a while the privilege was available only to Muslims [9, p. 216-217]. On the other hand, the peasants inhabiting the lands, formerly owners of their plots, were considered to have merely lease in the Ottoman system. ${ }^{6}$ However, they could sell their land if they obtained the sipahi's consent - which after a while became just a formality that a special tax, tapu, was paid for, and a certificate received in return ${ }^{7}$, and their sons could inherit the same rights. Furthermore, Ottoman regulations for the territory of Serbia continued to use the word baština to signify their rights. Thus peasants still believed that they had private property, as in ages past (and considered the tapu to be proof of property), ${ }^{8}$ leading to the paradox of the serf seemingly having more rights to his land than the feudal lord. Still, the sipahi's consent was needed even for such things as the erection of buildings or the choice of culture to be planted on the land $[1, \mathrm{p} .84-89$, 98-111].

Some of the Sultan's land, however, was not given to the sipahi, but was leased out to various persons, who paid the rent for it on a yearly basis; such lands were known as mouqat'a. Although their regime was different in the government's eyes, the duties of peas-

${ }^{3}$ The Ottoman system is usually referred to as feudal in Serbian literature. However, Nedeljković warned against using this term, since the Western European feudalism has completely different relations between the noble landowner and the serf; still, he acknowledged that there was much greater similarity regarding property rights $[1$, p. 333-335; cf. 5, p. 464]. Some modern scholars, likewise, think that the system cannot be considered feudal because it does not fully correspond to Western feudalism. See [6, p. 19-24] and references there.

${ }^{4}$ The main among those was $10 \%$ of the gathered crops, but there were many others, relating to other agricultural activities (e.g. growing fruit, making honey, milling flour) as well as relevant occasions in the peasants' life (weddings, deaths); for a detailed list of these as well as taxes owed to the government regardless of land ownership, see [7, p. 274-318; 8, p. 361-364, 382-440; 1, p. 89-98].

5 There were also smaller pieces of land that where given to the sipahi for their personal use; in Serbia, those were called aliya. Many sipahi leased out those lands as well [1, p. 111-115].

${ }^{6}$ As Nedeljković points out, "whoever was, in the period before the Ottoman conquest, a landowner (baštinik) - either a nobleman or a free man - he stopped being one" [1, p.56].

7 The proper name of the certificate was tapunama, but the word tapu (tapija in Serbian) was also used.

${ }^{8}$ Ninčić considered baština to be private property even under the Turks, but Nedeljković refuted his arguments, proving that the legal characteristics of baština under Ottoman rule show that it was a form of hereditary lease; as was already pointed out elsewhere, another flaw of Ninčićs argumentation is that it relied heavily on Roman law, which is incompatible with the concepts of property in the Sharia system. See [10, p. $10-25 ; 1$, p. 104-111; 11, p. 6-7]. Novaković, on the other hand, compared the old baštinik and the owner of the chiftlik (see below) [9, p. 221-224]. 
ants who lived there were the same as on the lands of the sipahi. Finally, a form of private property - mulq - did exist in the Sharia system, but in Serbia it was mostly limited to land and buildings in cities [1, p. 341-343; 5, p. 468]. ${ }^{9}$

Of course, the rules of the system were frequently broken and abused. One of such abuses was the forceful introduction of chiftlik, an institute close to private property, which was originally bestowed by the Sultan to distinguished individuals, but usually on barren land. In the late $16^{\text {th }}$ century, however, janissaries started seizing land from baštiniks or even sipahi ${ }^{10}$ and forcing the peasants to pay a high rent (and provide kuluk - mandatory free labour) in order to be able to use their own land - of course, in addition to the rent legally owed to the sipahi $[16$, p. $390-395 ; 1$, p. 122-134]. All of this was very hard on the people, since the main occupation of the Serbian population at the time was agriculture in its broadest sense, mainly animal husbandry $[17$, p. 126-135; 3, p. 29-38; 18, p. 25-28; 19 , p. 166-176; 20, p. 9-14].

Particularly since the Austro-Turkish wars of the late 17th and early 18th century, the territory of Serbia witnessed several rapid changes between relatively mild and completely legal regimes and periods of great peril, exploitation and abuse of power $[21 ; 22$, p. 146-237; 19, p. 13-24.]. The last and worst of these was the period of the rule of the rebel janissaries (dahiyas, 1801-1804), which led to the First Serbian uprising in 1804 - which, in turn, tied in to the Russo-Turkish war of 1806-1812. Although the Treaty of Bucharest obliged the Ottoman Empire, among other things, to give autonomy and amnesty to the Serbs, the Porte took advantage of Russia's war with Napoleon and put a bloody end to the insurrectional Serbian state, ignoring the treaty. ${ }^{11}$ However, as the rule of the new Belgrade vizier, Suleyman Pasha, became as brutal as that of the janissaries, the Second Serbian uprising broke out under the lead of Miloš Obrenović - this one short and efficient, prudently finalised by negotiations when the military force of the insurgents started weakening. ${ }^{12}$

\section{THE PERIOD OF DUAL GOVERNMENT (1815-1830) AND REVOLTS OF THAT TIME}

The period after the Second Serbian uprising has been called period dvovlašća by Serbian authors - the period of dual government - due to the parallel existence of Ottoman and Serbian government structures. (Another term in use is "half-autonomy" [19, p. 69].) This period is considered to start with the treaty of Miloš Obrenović and Marashli Ali Pasha, which ended the uprising. The treaty concerns primarily judicial and taxation mat-

\footnotetext{
${ }^{9}$ For these and other institutes of the Sharia and Ottoman property law see [12, p. 1-25; 1, p. 16-42, 66-122; 13, p. 337-434; 14, p. 98-121; 15].

${ }^{10}$ As Todorović points out, this causes a peculiar case of the obtainer of the land having more right to it than the person he obtained it from [5, p. 471-472]. This is just additional proof of the illegal introduction of chiftlik into Serbia.

${ }^{11}$ To learn more about the events of this period, see $[23$, p. $137-165 ; 24 ; 25 ; 26 ; 27 ; 28$, p. 178-183; 29 , p. 193-202; 30, p.7-95]. For the transformation of property during the uprising, see [1, p. 139-165; 3 , p. 51-59].

12 The uprising was preceded by another revolt against the Turks - Hadži-Prodan’s — but Miloš helped the Ottoman authorities quench it (with as little bloodshed as possible), not out of loyalty, but because he thought the time wasn't yet ripe for an uprising. For more details on these events, see [31, p. 6-30; 32 , p. $56-133 ; 33 ; 23$, p. $165-174 ; 30$, p. 96-108].
} 
ters, and does not make major changes in the general Ottoman government or property regime $^{13}$ - although the feudal rent within it was reduced to a legal minimum [1, p. 172$173 ; 19$, p. 70-73]. However, during this fifteen-year period, many de facto changes were introduced by Miloš Obrenović, some of them pertaining to or affecting land ownership. ${ }^{14}$

Miloš did his best to control the sipahi with various uses and abuses of his authority, thus greatly reducing their power $[8$, p. 295-307; 1, p. 174; 19, p. 74-80]. By 1819, he had successfully expelled the chiftlik from Serbia ${ }^{15}$, but he also fought those of the sipahi that were demanding illegal kinds and amounts of tolls from the people [8, p.364-372; 35, p. 43-49]. In 1816, he started leasing the mouqat'a, until at last all were under his control, and leased them out in turn to the local elders ${ }^{16}$, mostly his relatives and supporters [1, p. 174-175; 8, p. 372-381]. ${ }^{17}$ This led to a slightly paradoxical situation - that the Serbian authorities were more willing to help the plight of those peasants who lived and worked under Turkish than under Serbian lords. Miloš was always ready to help in any conflict between the peasants and the sipahi and to fight for the reduction of taxes the peasants were paying. However, he and his supporters had frequently raised those very tolls on the lands that they were leasing, and many people did not dare complain; when they did, their suits and complaints frequently yielded no results [8, p. 379; 2, p. 53-57, 207-209]. Similarly, while Miloš strived to reduce kuluk demanded by the Turks (Ottoman population) to a minimum, he and the other elders also demanded free labour on their lands from the peasants - a relationship that was easily and frequently abused, leading to great dissatisfaction of the people [8, p.438-440, 486-496].

In order to increase the country's population and to lure in settlers from other Ottoman territories and Austria, Miloš gave them abandoned land, introduced temporary tax exemptions and allowed them to cut the forest in order to occupy more land for settling. The measures were very successful and caused a dramatic increase in population, but they also caused great displeasure in the local population, who saw the newcomers as intruders with undeserved privileges. They were frequently forced to leave villages where they had first settled, while their property was looted by the local population; however, this only caused the privileges to increase, with Miloš even commanding that land be taken away from those who have too much of it and given to the new settlers. Although many authors claimed that he was against large landowners, the actual reason was merely the ability to cultivate the land $[8$, p.254-255; 19, p. 192-196; 37, p.68-69; 38, p.483]. After a while,

${ }^{13}$ In his history of the Ottoman Empire, Kia presents it as if Serbia gained autonomy right after the Second Serbian uprising, which was only formally recognized after the Treaty of Edirne; such a view must be considered incorrect [34, p. 106-109].

${ }^{14}$ Of course, other highly relevant changes have been introduced in other areas. For example, on Milošs changes in administration and especially the judicial system, see [8, p. 287-295, 308-327]. 173].

${ }^{15}$ Miloš asked for that in 1815 and Marashli agreed, but the Porte confirmed it only in 1819 [1, p. 172-

${ }^{16}$ It should be noted that the elders in question were merely holders of important local functions and those who have distinguished themselves during the uprising; there was no noble class in Serbia and no intention to introduce one. Despite different tendencies during the First Serbian uprising, Russia was of the same opinion now. During the preparation of the draft for the Hatt-i-humayun of 1830, the Russian representative in Constantinople, Ribaupierre, told Dimitrije Davidović that Serbs should not introduce nobility, that the boyars were the main cause of the people's misfortunes in Wallachia and that meritocracy was superior to hereditary titles [36, p. 190-191].

${ }_{17}$ This included not only the Sultan's lands, but the mouqat'a in the broader sense of the word various sources of government income that could also be leased out to individuals, such as customs, ferries, various market tolls and so on. 
newly formed Serbian courts started giving out tapu [39, p. 5-6]: jurisdiction was gradually shifting towards Serbian rule, but the property law was still fully Ottoman. ${ }^{18}$

It is worth noting that, while Miloš acknowledged his government to be hard on the people, he did not consider it corrupt and unjust. Quite to the contrary: comparing his reign to the anarchy of the First uprising or the abuses of the Turks, he believed himself to be the saviour of the people [8, p.497-498]. While it cannot be denied that his government and his efforts had indeed brought the first steps towards freedom from the Ottoman rule and the best position of Serbia since the 15th century, this cannot be a reason to ignore the flaws of his regime. And the same was, indeed, the case during his reign: although the people mostly supported Miloš and acknowledged the good that he had done, there were also many complaints about his abuse of power - which led to multiple revolts against his rule.

The first of these was the revolt of Sima Marković in 1816-17: the knez was plotting against Miloš with the Serbian emigration in Bessarabia. After that was discovered, he started a revolt with two other elders; although its beginning was very strong, it was quickly suppressed [41, p.333-340]. In the spring of 1821 came the revolt of Marko Abdulić and Stevan Dobrnjac. Caused primarily by the conflicts of these two elders with Miloš over matters of trade and taxation and their yearning for more power at the expense of the general struggle for autonomy, it was small in scale and quickly suppressed. Thus, neither of these rebellions can be deemed a peasant revolt: both were in essence political. ${ }^{19}$ It is noteworthy that, despite the weakness and personal motivation of the revolt, Miloš tried presenting it to the Turks as the spreading of the much more serious uprisings against the Turks in Greece, Walachia and Moldavia, in order to demonstrate his own loyalty to the Sultan [8, p. 501-517].

In late 1824, Miloš discovered a conspiracy to stage another revolt against him, focused in the Rudnik nahia. ${ }^{20}$ Although at first he was led to believe that the emigration was plotting against him again, the conspiracy turned out to have been a result of the dissatisfaction of the people throughout Serbia. The conspirators were strictly punished, some of them executed; the main reason for revolt they had revealed during questioning were too high tolls and the abuse of power by Miloš and his brothers [8, p. 565-567; 2, p. 58-81].

Although the conspiracy seemed to have been mostly rooted out, it was in January of 1825 that the greatest rebellion so far broke out, obviously outscaling the others [2, p. 7]. It started as a revolt of the people of the Smederevo nahia against corrupt local authorities: they demanded that those officials be replaced with individuals of their own choosing, without claiming to oppose Miloš himself. However, they were in league with the aforementioned conspirators, and more people were spontaneously joining the revolt as it grew (including some of those sent to help subdue it), amassing a considerable army. In order to preserve the peace, Miloš was inclined to agree; however, one of those candidates of the people, Miloje Popović Đak ${ }^{21}$, kept spreading the unrest, sending his brother to raise the

${ }^{18}$ Ottoman terminology also remained in force for a long time, particularly in colloquial language [40, p. 144].

19 That is not to say that they were not motivated by economic reasons - but those of the holders of power, and not the peasant populace [2, p. 48-53].

${ }^{20}$ For the administrative division of Serbia within the Ottoman Empire, see [42, p. III-IX].

${ }^{21}$ Đak used to be a priest, but he rejected his vows during the First uprising, serving for a while as a clerk under the new government. As Karađorđe's state fell apart in 1813, he fled to Pančevo; he returned to 
Požarevac nahia to arms as well. Đak was slowly gathering an army, pillaging the property of many local officials, demanding mostly a reduction of taxes. On January 20th, the rebels held an assembly in Topola that compiled a list of demands, which was then sent to Miloš: the key points were that the abuse of power should be stopped, taxes and other tolls, as well as kuluk, reduced, and free trade allowed - thus showing a more general and deeper dissatisfaction of the people. ${ }^{22}$ Another letter sent to Miloš on the following day was signed by "all the poor people of 12 nahias" - i.e. from the whole of Serbia [8, p. 568-577; 2, p. 81-126].

Although Đak's supporters were numerous, they were an angry crowd rather than an army; most were more inclined to pillage and run than to fight, and the harsh winter conditions frequently sent them back into the safety of their homes. ${ }^{23}$ Thus many of them fled at the sight of Milošs army, commanded by Toma Vučić Perišić, and when Đak himself was caught and executed, the rebellion died down quickly [8, p. 577-586; 2, p. 127-151]. Still, its consequences were significant: issuing a proclamation, Miloš asked every nahia to point out which regulations they found unacceptable, although he pointed out that all were made in the interest of the people. The assemblies of the nahias phrased their answers carefully, trying not to criticise Milošs government, but merely to complain about concrete issues ailing them. ${ }^{24}$ Miloš relied not only on these answers, but also on the reports of his spies. At the assembly held on the 5th of May in Kragujevac, Miloš proclaimed a reduction of taxes. A number of representatives of each nahia were chosen as representatives for further assemblies, but their jurisdiction was soon extended to controlling the local authorities and protecting the people against the abuse of their power. Generally, more attention was paid to the selection of fair and reliable people as elders from that moment on [8, p. 587-599, 605-612; 2, p. 152-182].

It is noteworthy that Đak's revolt gave Miloš two weapons to use in the fight against the Ottomans. Firstly, Miloš once again tried to use a revolt as a political weapon, telling the vizier that the people had rebelled against Milošs turkophilia and the Ottoman government in Serbia. ${ }^{25}$ Secondly, it was the reason for the creation of professional armed

Serbia in 1815 as a merchant. He seems to have even performed some confidential business for Miloš [8, p. 570-571].

${ }^{22}$ As Đorđević pointed out, these demands were nothing new, but showed the same problems that were noticeable year after year [2, p. 185-187]. Stojančević, on the other hand, believed the monetary obligations to have been the hardest for the people to bear, and thus the main cause for dissatisfaction [19, p. 128].

${ }^{23}$ It is also possible that Đak's insistence on trying to negotiate and waiting to see if Miloš would accept the demands of the Topola assembly caused the revolt to lose momentum [2, p.117-118].

${ }^{24}$ A good example of Milošs reactions to criticism was the affair of Nikola Nikolajević and Lazar Todorović, both Milošs close confidants, who had in the autumn of 1821 decided to write an anonymous essay urging the Prince to correct his flaws, for his own good and the good of the people. However, the rough draft of that essay was found in Todorovićs possession, which led to their imprisonment, investigation and accusations of them having supported Abdulićs revolt. While Todorović confessed to writing the essay, claiming to have had the best intentions, Nikolajević kept denying his involvement. In the end, Nikolajević was killed on Milošs command, while Todorović was forgiven and restored to service. Afterwards Miloš published a proclamation to the people, asking all who have suffered any form of injustice or were aware of some flaws of his government to speak out, so he could solve those problems; however, this was a trick to find out what the people thought about him, and those who actually spoke out strongly against him were later punished [8, p. 518-547].

${ }^{25}$ Similarly, Miloš tried blaming the revolt on the emigrants in Bessarabia (and their connections with the Hetairia) in order to prevent their return to Serbia, but with practically no factual basis. Cunibert also heavily relied on these Milošs claims [2, p. 190-203; cf. 43, p. 170-184]. 
forces in Serbia - although they were at first designated as a special sort of policemen, in fear of Turkish reprisal for the introduction of an army [8, p. 599-605, 613-614].

Another relevant uprising was Čarapićs's revolt in April 1826, sometimes referred to as the ending of Đak's [2, p. 8]. Đorđe Čarapić, ${ }^{26}$ formerly one of Milošs clerks, was one of the participants in Đak's revolt, but he had fled to Austria after it was subdued, where he had plotted another revolt, mostly out of personal dissatisfaction. However, the conspiracy was discovered and the leaders of the rebellion quickly slain as soon as it had started [8, p. 617-637].

\section{THE HATT-I SHERIF OF 1830 AND 1833 - REVOLTS AS MILOŠ'S WEAPON}

Despite the long diplomatic struggle of both Serbian and Russian representatives in Constantinople, in the end it was only the direct military action of Russia (the war of 1828-29) that forced the Ottoman Empire to honour its previous obligations. Even after the Treaty of Edirne (Adrianople) of 1829, the Porte kept trying to dodge its duties; it took another round of negotiations, persuasion and bribery to finally secure the result. ${ }^{27}$ The Hatt-i sherif of 1830 was solemnly read in Belgrade on November 30th and December 1st, first in Turkish and then in Serbian [36, p. 285-300].

The act brought many long-expected changes to Serbia, making it an autonomous province of the Ottoman Empire, a vassal of the Sultan with independent internal rule and a hereditary Knjaz (Prince). ${ }^{28}$ Among other things, it was decreed that the six nahias, torn away from Serbia in 1813, would be restored, and that a total sum of taxes would be paid for the entire land. ${ }^{29}$ All Turks except those serving in city garrisons were to move out of Serbia within a year: they could either sell their lands to Serbs, or have the incomes from those lands be joined with the total sum of tax. No Serb could be forced to serve a Turk in any kind of service. ${ }^{30}$

All of this was supposed to drastically improve the position of the Serbian people; however, the Porte was stalling yet again, telling that there were more pressing matters at hand, refusing to return the nahias that it had promised and instructing the Turkish population (that had already begun selling their property) not to leave Serbia [36, p. 303-409]. Even after it was forced to rely on Russian help to subdue the uprising of the viceroy of Egypt, Muhammad Ali Pasha, which had threatened to overthrow the Empire [36, p. 410$418 ; 46$, p. 56-58], it was not willing to calmly keep its word. In the meantime, the Turkish authorities in the neighbouring pashaliks - that the nahias that were supposed to be restored to Serbia currently belonged to - were abusing their power and molesting the Serbian population: demanding excessive tolls (including the chiftlik), commanding where

\footnotetext{
${ }^{26} \mathrm{He}$ was the son of Atanasije Čarapić, one of the participants of the First uprising, who had died in the battle of Prahovo in 1810, and the nephew of the famous hero Vasa Čarapić [8, p.617].

${ }^{27}$ For details see [32, p. 139-172; 41, p. 271-294, 377-522; 8, p. 1-54, 115-253; 36, p. 1-285; 44, p. 75$89 ; 19$, p. 135-148]. It's worth noting that the expenses of the deputation and the bribes for Ottoman officials were one of the more relevant reasons for high taxes and tolls of Milošs time [19, p. 133-134].

${ }^{28}$ Although both forms of the title, Knez and Knjaz, have been used throughout history, in Milošs time knez was merely the title of a local elder, while Knjaz was reserved for the central ruler; even the use of the title knez for elders of lower rank was prohibited in 1827 [45, p. 50; 28, p. 191].

${ }_{29}$ That way, the state would pay that amount to the Porte, while the matter of how it would get the money and what taxes it would impose on the population would be solely within its competence.

30 The Serbian translations of the texts of the Hatt-i humayun (both of 1830 and 1833) were published in [36, p. 604-607, 614-617].
} 
they had no authority to (such as in issues of marriage) and abducting and raping women. It was one of such cases of abduction that Miloš used in late 1832: he staged revolts against the corrupt Turkish authorities first in the Kruševac nahia, and then in the remaining five. After the revolt broke out, Miloš moved in with his army - allegedly to protect the people, in fact to occupy the territories he was entitled to. Although it was highly suspicious, to say the least, that the revolt broke out exactly in those six nahias that Serbia was promised by the Ackerman Convention, Milošs tactic had worked: the Porte agreed to confirm the borders of Serbia. [36, p. 418-463; 19, p. 153-154].

The Hatt-i humayun of 1833 was, in essence, an annex that finalised the matters that the one of 1830 had left unfinished. The new borders of Serbia were established and the taxes calculated accordingly; however, the Turkish population was allowed an additional five years to move out, and those residing in Belgrade could stay. ${ }^{31}$

From that point on, the Ottoman property system was no longer in force in Serbia and baština became property again. As Nedeljković has pointed out, that meant that every Serb could freely obtain or dispose of his baština, inter vivos as well as mortis causa, and had full freedom regarding his agricultural activities on it $[1$, p. 169-170].32 Of course, that did not mean the restoration of the medieval Serbian (feudal) baština: the society of that time was too different, and, although many medieval legal manuscripts survived in monasteries, after centuries of disuse "very few truly understood what was written in them" [48, p. 103]. The system of taxes and tolls was also changing, although the old one was completely replaced only in 1835 [3, p. 138-139; 49, p. 13-15].

It bears mentioning that some elders were interested in keeping the Ottoman feudal system; rumours began spreading that the sipahi lands and rights will simply be given over to Serbian officials. However, Miloš was decisively against this, which he stated on the assembly held in Kragujevac in February 1834. Cunibert wrote that he officially proclaimed that the sipahi system was "forever destroyed in Serbia and will never be re-established in any form" [43, p. 347]. The phrase was since quoted by many authors (e.g. [19, p. 194-195]), but it actually does not exist in the official transcript of the speech [50; cf 37, p. 53; 5, p. 476]. Still, since the published speech was not given by Miloš, but read in his name, it is theoretically possible that he also made a direct address to the people, in which he could have pronounced the words that Cunibert quoted. Regardless of whether Miloš pronounced these dramatic words, the result was the same. The Ottoman property system was formally abolished: a new system of private property was to grow in its stead. ${ }^{33}$

31 This was the result of a compromise with the Russian government, more inclined to relieve the Porte of one of its duties now that they were military allies (and the Ottoman Empire, at least temporarily, a de facto protectorate of Russia) after the joint action against the Egyptian rebels [36, p. 464-481]. However, the prolonged deadline was again breached, and some of the Turkish population remained in Serbia for decades to come; there were also practical difficulties with the selling of lands sometimes [1, p. 192-198].

32 Some special rules remained in force regarding the property of Orthodox churches and monasteries, which had a position similar to that of feudal lords under Ottoman rule and preserved it after 1833 . The position of waqf lands was also different, and in 1839 they were given to Orthodox churches, to which many of them had belonged before the conquest [1, p. 183-192; 47, p. 255-256]. However, these complex questions deserve to be researched separately.

${ }^{33}$ Petrović claimed that this ended the first phase in the creation of free rural property, the termination of the sipahi system; it was now time for the second phase - the legal securing of this property [35, p. 82]. 


\section{MILETA'S REVOLT AND THE SRETENJE CONSTITUTION OF 1835}

Despite the general improvement of the legal position of peasants, there were still abuses by many local elders, particularly in the six freshly returned nahias. Miloš was taking measures against this (although he was also guilty of abuse occasionally), but they were more frequently righting individual wrongs then generally preventing the abuses $[19$, p. 200-211]. Additionally, some of those measures - such as his personal intervention in the judiciary, mostly unsystematic and even whimsical ${ }^{34}$ - could not be considered good for the country as a whole [38, p.366-370; 8, p.476]. Besides, the economic position was yet to be improved, since trade was limited and most peasants had no direct way to improve their welfare by selling their cattle. This situation led Slobodan Jovanović to remark (perhaps exaggeratedly, but effectively) that in this period there existed free peasant property, but no free peasants. Stojančević opposes, claiming that the economic burden that peasants bore was related to the increased expenses of the autonomous Serbian state in the making [52, p. 78-79; cf. 19, p. 158-190].

In January 1835, a revolt broke out under the leadership of Mileta Radojković. ${ }^{35}$ The main causes are usually considered to be Milošs absolutist government and the dissatisfaction of the people with their economic and legal position; however, there is also a theory according to which the peasants were generally satisfied with the development of both those issues, and that Radojković and his narrow circle of supporters (mostly elders who wanted a greater share in government) tricked several thousand people into joining by telling them they were going to defend the borders against Turks by Milošs command! But even according to this interpretation, the main reason was an agrarian one: the distribution of the former aliya and other lands that had belonged to Turks who had moved out of Serbia. Within a week, the rebels reached Kragujevac. Miloš entered into negotiations with them and promised to convoke an assembly to discuss all matters of relevance to the people and state. The assembly was held on Candlemas (Sretenje), and it was on it that Miloš gave Serbia its first constitution [19, p. 270-280; 37, p. 125-144].

It must be noted that the Sretenje Constitution made more changes in the character of central government (which is not the subject of this paper) than in the agrarian regime, and that it was extremely short-lived: it was abolished after approximately six weeks due to the pressure from the Porte and Russian and Austrian diplomats, since Serbia, as a vassal state, had no right to promulgate a constitution, and its contents were not to their liking [53, p. 101-102; 54, p. 78]. ${ }^{36}$ Still, its property regulations are relevant not only because they were the first written guarantees of property rights, but even more so because they set a foundation for numerous shorter legal acts that were to come after it and that remained in force.

All these regulations are contained in Chapter eleven of the Constitution, titled "The nationwide rights of Serbs" [47, p. 18-19]. Art. 119 proclaims: "The property of every Serb,

${ }^{34}$ This could be attributed to his general view of himself as a mentor, fatherly figure to the people and subsequent wish to get involved even in individual and private matters. [51, p.X-XI].

${ }^{35}$ It is noteworthy that Radojković was one of the main agents Miloš used to stage the revolts in $1832[36$, p. 422-456].

${ }^{36}$ It is widely considered that Miloš was glad to be rid of the Constitution, since it limited his power and was imposed onto him; however, there is enough evidence that Miloš was planning to create a constitution well before Mileta's revolt, maybe influenced by Vuk Karadžić (and that he tried saving it when the Porte intended to abolish it) to refute this idea [54, p. 73-74; 55, p. 40-53; 19, p. 242-243]. Thus the revolt must be considered a factor that quickened, and not caused, the arrival of the constitution. 
whatever it might be, is untouchable. Whoever dares to wilfully disturb another's goods and property, and either claim it or impair it, he shall be considered a violator of nationwide security, whoever he may be and wherever from he may be." The following three articles proclaim that the government ${ }^{37}$ has the right to claim someone's land if they need to be used for a public benefit, but only with providing the owner with a fair compensation, calculated by experts (art. 120); that every Serb may decide to move to other parts of the Ottoman Empire or to a foreign land, as long as he obeys the relevant laws in the process (art. 121) and that each Serb must pay the determined taxes and help with communal needs, such as the building of bridges and the clearing out of roads (art. 122). Art. 124 proclaims that no Serb owes kuluk to any government official, save for the erection of buildings needed for public use and with fair compensation.

Finally, art. 128-129 proclaim the general regime of various types of land. The first proclaims that "all land owned by the Serbian people belongs to each owner as natural property, that anyone can dispose of according to his will", only with the note that the sale of land must be public. The latter proclaims forests (former aliya) to be public goods that anybody could use and nobody could claim them for themselves.

Very soon afterwards, a Regulation for lawsuits regarding land was promulgated: all such suits were from then on in the jurisdiction of the village kmet and captain - the lowest, entirely local, courts - on the account of it being the easiest for them to solve such a case, having direct access to the property in question..$^{38}$ In addition to some more detailed procedure rules, the regulation also contained a rule for the clearing of land ( $k r c ̌ e v i n a)$, according to which such land belonged to the one who had cleared it, regardless of whether he had performed the clearing in the area of his own village or not [47, p. 55-66].

A few more regulations improving the position of peasants followed in short succession during the following few years (1835-37), such as the general proscription of mandatory labour (except in strictly determined cases, as a form of payment of local tolls to the kmet) and other abuses of local power, the proclaiming of both aliya and wastelands public lands and the prohibition of letting cattle into the territory of another village, the rules for equal division of the aliya between neighbouring villages, another general guarantee of the inviolability of private property and the abolition of kuluk [47, p. 57-58, 84, $85,150,217-218]$.

A different intervention of the state in the area of property rights in 1836 bears more detailed mentioning: a regulation that certain items of a debtor's property could not be sold to settle their debts, meant to protect the overly indebted population. City-dwellers could not have the house they lived in sold; for rural inhabitants, the minimum included not only the house, but also the land around it $\left(\right.$ baština $^{39}$ ), two oxen and a cow [47, p. 119]. In the context of increasing economic and social changes, this measure was useful and justified [35, p. 89-90]. ${ }^{40}$

${ }^{37}$ This refers to the central organs of government - the Knjaz and the State Council.

${ }^{38}$ The parties could reach the district courts - the lowest instance mentioned in the Constitution only by appealing to their verdicts. Cf. [47, p. 13]. With the exception of the few written regulations listed here, judges primarily relied on customary law [56, p. 456].

${ }^{39}$ In this case, baština meant a quantitatively unspecified minimum, and not the whole property [35, p. 88-89].

40 It was abolished in 1838 due to some abuses, but similar measures were re-established later and revoked only in 1929. This caused an almost century-long hiatus in the development of hypothecary credit 
Another intrusion of the government in the private property rights in the interest of the people was the mandatory process of ušoravanje - the transformation of scattered settlements into more compact ones, with streets ${ }^{41}$ - that was made obligatory in 1837 , though the process itself had started in Western Serbia in 1830 [47, p. 175-176]. Although some people opposed the plan and even moved further into the hills, it was generally successful in reallocating the population to more favourable sites and creating larger communities [28, p. 194; 37, p. 80-83].

\section{THE TURKISH CONSTITUTION OF 1838 AND THE RESTORATION OF LANDS ACT}

Once opened, the constitutional question remained active: finally, Miloš asked the Porte to provide a constitution for Serbia. After a lot of negotiations and drafting [19, p. 280-289; 37, p. 158-197], a new Constitution was promulgated in December 1838, in the form of another Hatt-i humayun, earning the colloquial name Turkish Constitution $[58,1-15]$. It was shorter and less liberal than the Sretenje Constitution, but it still contained some articles relevant to the issue of land property. Articles 27-28 proclaimed generally the judicial protection of rights of the Serbian population, remarking that confiscation of property could not be a valid punishment for any crime. Art. 46-47 proclaimed that every Serb was the sovereign lord of his property, that he could sell or leave it to someone by will and that nothing but a valid judicial verdict could deprive one of this right. Art. 49 abolished kuluk, while art. 59 proclaimed that the abolished regime of sipahi lands could never again be introduced in Serbia.

Displeased with the political limitations the Constitution imposed on him and under pressure by his opposition (and after yet another revolt, but this time a military one in favour of Miloš and against the elders), Miloš abdicated from his throne shortly after this, in 1839 [19, p. 289-290; 37, p. 451-481], but this didn't hinder the reform process; on the contrary, it culminated in the Restoration of Lands Act, promulgated by the Regency in July 1839 [58, p. 103-107]. ${ }^{42}$ The act starts with the proclamation of some general standards - every Serb's right to his land, which can and must be protected in courts. (Art. 1-2.) However, not all land disputes were treated equally. Extinctive prescription was introduced for anything that was done before 1816, during the period of Ottoman judiciary, and such an owner could not sue or be restored to his land. It is proclaimed that from 1816 until the Hatt-i humayun of 1833, only those who had tapu were considered owners of their lands; but from 1833 on the landholders who had no tapu where equally considered owners - and thus anyone who had possession of a plot of land became its owner. (Art. 4-6.) A rather strange phrasing is used here: "all Serbs became true owners of their lands"; Nedeljković remarks that it may be a logical fallacy, but is supposed to signify that Serbs became actual owners of the lands they had already considered to be their own [1, p. 180].

in Serbia and impeded rural economic development due to more and more parcels of land being of the minimal size [37, p. $68 ; 57$, p. 38-43; 39, p. 7].

41 The term comes from šor, the Hungarian word for street [28, p. 193].

${ }^{42}$ It's curious to note that 1839 brought the end to the sipahi system in the Ottoman Empire as well [59, p. 55-133; 60, p. 339-346]. 
Thus, any tapu from 1816 on was to be considered solid evidence of ownership; from 1833 on, even if neither party had tapu, the one who held the land first was to be considered its owner. For the six nahia that were adjoined in 1833, both rules would apply from that point on. Of course, any verdicts regarding land ownership which were rendered during that time remained in force. (Art. 8-11.) This limitation might seem unjust, but it was introduced to strengthen the new legal order and prevent unnecessary lawsuits. On the one hand, proving ownership that arose before Milošs reign would be exceedingly hard under the circumstances. On the other hand, an official interpretation issued in 1843 pointed out that it was reasonable to assume that nobody could have usurped land during Ottoman rule [61, p. 206-207].

The remaining articles (12-17) contain special rules for certain types of cases. Art. 13-17 make special remarks for certain types of immovable assets: while there were no special terms for "clear" land such as fields and meadows, or for buildings, there were some for orchards and vineyards. Thus, if the owner of an orchard did not have tapu, and the possessor had, in the meantime, either increased the value of the orchard over half the previous value or built a house and settled there, the owner could not get the orchard back, but merely receive monetary compensation. In the case of vineyards, the right of an owner who had abandoned his vineyard for seven years or more ended through extinctive prescription, because an abandoned vineyard would be ruined within that period. These rules show that the legislator took into account the particulars of the nature and needs of certain types of land.

Art. 12 points out that "there have been cases" of children leaving their property after their father's death (either because of their mother's remarriage or in order to find work) and those lands falling into the hands of another. If such people had no other baština and wanted to return to the land of their birth, the law proclaims that "humanity itself asks and demands" that land is returned to them, if that can be done without damage (presumably, to the new possessor), or, if not, that they receive another equivalent parcel. Such cases, moreover, were always to be decided by the Ministry of Justice. Art. 17 states that, "as it goes without saying", those who have willingly sold, given or in any other way transferred property of their land to another had no right to demand it back. A well-developed legal system would have no need for such regulations, particularly those of art. 17: however, they cannot be ascribed to the legislator's ignorance, since the act seems to notice its own redundancy. It is thus obvious that the ratio of these norms was to eliminate any possible doubts among the people who were both largely uneducated and used to legal insecurity regarding their property, and thus, again, to reduce the numbers of lawsuits that would have to be turned down by courts, but would still take up their time. ${ }^{43}$

\section{CONCLUSION}

The relationship between peasant rebellions and land reform in Milošs Serbia is a complicated one. The Serbian uprisings themselves obviously contained an element of agrarian dissatisfaction (though they cannot by any means be reduced to it), and Miloš later headed the continuation of the same struggle (both for independence and for land reform) by diplomatic means. However, the very people who were his main supporters

\footnotetext{
${ }^{43}$ However, this was not enough to prevent an overflow of lawsuits in courts [62, p. 28].
} 
and shared his general goals also frequently rebelled (or at least complained) against the methods he was using. The reason for this is twofold: on the one hand, Miloš and his officials were known for many abuses of power; on the other, even those measures that were introduced in the best interest of the people were frequently unpopular, particularly when they meant drastic changes in the existing customs and way of life. Finally, having been both at the head of revolts against the Ottomans and the target of the dissatisfaction of his people, Miloš was proficient in using revolts as a political weapon by twisting the public presentation of their causes or, as in the case of the six nahias, staging them outright.

The whole 1815-1830(33) period was a lengthy preparation for the abolishment of the Ottoman system. Once that goal was complete and private property introduced, it needed an entirely new legal framework. The creation of that new system might have been gradual and unsystematic (only the Civil Code of 1844 will attempt to introduce comprehensive written property law that would have supremacy over customary law), but it was still a slow yet certain road to legal stability and economic recuperation which Serbia had lacked over the tumultuous centuries of Ottoman rule.

\section{References}

1. Nedeljković, B. M. (1936) Istorija baštinske svojine u novoj Srbiji od kraja 18 veka do 1931. [The history of baština property in modern Serbia from the end of the 18th century to 1931.] Beograd: Geca Kon.

2. Đorđević, M. (1953) Đakova buna: političko-istoriska studija. [Đak’s revolt: a politico-historical study.] Beograd: Prosveta.

3. Srdanović-Barać, O. (1980) Srpska agrarna revolucija i poljoprivreda od Kočine krajine do kraja prve vlade Kneza Miloša (1788-1839). [The Serbian agrarian revolution and agriculture since Koča’s Krajina until the end of the first reign of Prince Miloš (1788-1839).] Beograd: SANU.

4. Ranke, L.von (1829) Die serbische Revolution. [The Serbian revolution.] Hamburg: Friedrich Verthes.

5. Todorović, M. (2012) 'Hatišerifi iz 1830. i 1833. godine i zemljišna svojina u Srbiji' [Hatti- sharifs of 1830 and 1833 and land porperty in Serbia], Zbornik radova Pravnog fakulteta u Nišu, 62, pp. 463-478.

6. Todorović, M. (2016) Tapijski sistem u XIX veku - Otomanska zaostavština južnoslovenskim narodima. [The tapu system in the XIX century - an Ottoman endowment to the South Slavs.] PhD thesis. University of Belgrade Faculty of Law.

7. Petrović, V.J. and N.J. (1882) Građa za istoriju Kraljevine Srbije: Vreme prve vlade Kneza Miloša Obrenovića, knjiga prva - od 1815. do 1821. godine. [Materials for the history of the Kingdom of Serbia: The period of the first reign of Prince Miloš Obrenović, book one - 1815 to 1821.] Beograd: Srpska državna štamparija.

8. Gavrilović, M. (1909) Miloš Obrenović, knjiga druga (1821-1826). [Miloš Obrenović, book two (1821-1826)] Beograd: Davidović.

9. Novaković, S. (1887) 'Pronijari i baštinici (spahije i čitluk-sahibije): prilog k istoriji nepokretne imovine u Srbiji XIII-XIX veka' [Proniars and baštiniks (sipahi and chiftlik-sahibi): a contribution for the history of immovable property in Serbia of the $13^{\text {th }}-19^{\text {th }}$ centuries], re-published in Novaković, S. (2002) Narod i zemlja u staroj srpskoj državi. [People and land in the old Serbian state.] Beograd: Zavod za udžbenike i nastavna sredstva, pp. 167-237.

10. Ninčić, M. (1913) Pitanje o svojini zemlje u Srba pod Turcima (odštampano iz "Dela"). [The question of the Serbs' land property under the Turks.] Beograd: Dositije Obradović.

11. Kršljanin, N. (2009) Pravni režim zemljišta u novovekovnoj Srbiji pre donošenja Srpskog građanskog zakonika: običajno pravo i sudska praksa. [The legal regime of land in the Modern Age Serbia before the Serbian Civil Code: customary law and judicial practice.] Master thesis. University of Belgrade Faculty of Law.

12. Ninčić, M. (1920) Istorija agrarno-pravnih odnosa srpskih težaka pod Turcima: I deo - ranije doba. [The history of agrarian-legal relations of Serbian peasants under the Tuks: Part I - earlier age.] Beograd: Geca Kon.

13. Hammer, J. von (1815) Des osmanischen Reichs Staatsverfassung und Staatsverwaltung. Erster Theil. Die Staatsverfassung. [The state organisation and state administration of the Ottoman Empire. Part one. The state organisation.] Wien: Camesinaschen Buchhandlung. 
14. Johansen, B. (1988) The Islamic Law on Land Tax and Rent: The Peasants Loss of Property Rights as Interpreted in the Hanafite Literature of the Mamluk and Ottoman Period. London - New York - Sydney: Croom Helm.

15. Sait, S. and Lim, H. (2006) Land, Law and Islam: Property and Human Rights in the Muslim World. London - New York: Zed Books.

16. Vejnstejn, Ž. (2002) 'Balkanske provincije (1606-1774)' [Balkan provinces (1606-1774)], in Mantran, R. (ed.) Istorija Osmanskog carstva. [The history of the Ottoman Empire.] Beograd: Clio, pp. 346-410.

17. Vučo, N. (1955) Privredna istorija Srbije do Prvog svetskog rata. [The agrarian history of Serbia until World War I.] Beograd: Naučna knjiga.

18. Protić, Lj. (1953) Razvitak industrije i promet dobara u Srbiji za vreme prve vlade kneza Miloša. [The development of industry and the commerce of Serbia during the first reign of Prince Miloš.] Beograd: Rad.

19. Stojančević, V. (1966) Miloš Obrenović i njegovo doba. [Miloš Obrenović and his age.] Beograd: Prosveta.

20. Đorđević, T. R. (1983) Iz Srbije Kneza Miloša: Kulturne prilike od 1815. do 1839. godine. [From the Serbia of Prince Miloš: Cultural circumstances from 1815 to 1839.] Beograd: Prosveta.

21. Tričković, R. (2013) Beogradski pašaluk 1687-1739. [The Belgrade Pashalik in 1687-1739.] Beograd: Službeni glasnik.

22. Zirojević O. (2007) Srbija pod turskom vlašću 1459-1804. [Serbia under Turkish rule in 14591804.] Beograd: Srpski genealoški centar.

23. Krstić, N. (1883) Istorija srpskog naroda. [The history of the Serbian people.] Beograd: Kraljevsko-srpska državna štamparija.

24. Ćorović, V. (1937) Karađorđe i Prvi srpski ustanak. [Karađorđe and the First Serbian uprising.] Beograd: Kolarčev narodni univerzitet.

25. Nenadović, K.N. (1903) Život i dela velikog Đorđa Petrovića, Kara-Đorđa, knjiga I (verno preštampano od 1883). [The life and deeds of the great Đorđe Petrović, Kara-Đorđe, book I.] Beograd: Savić i Komp.

26. Nenadović, K. N. (1884) Život i dela velikog Đorđa Petrovića, Kara-Đorđa, knjiga II. [The life and deeds of the great Đorđe Petrović, Kara-Đorđe, book II.] Beč: Štamparija Jovana N. Vernaja.

27. Janković, D. (1983) 'Predistorija stvaranja srpske države Prvog ustanka' [The prehistory of the creation of the Serbian state of the First uprising], Anali Pravnog fakulteta u Beogradu, 1-4, pp.371-385

28. Ćirković, S. M. (2004) The Serbs. Malden - Oxford - Carlton: Wiley-Blackwell.

29. Jelavich, B. (1983) History of the Balkans, volume I: Eighteenth and Nineteenth Centuries. Cambridge - New York - Melbourne: Cambridge University Press.

30. Stojančević, V. (2000) 'Srpska nacionalna revolucija i obnova države od kraja XVIII veka do 1839' [The Serbian national revolution and rebuilding of the state from the end of the 18th century to 1839], in Stojančević, V. (ed.) Istorija srpskog naroda, peta knjiga, prvi tom: Od prvog ustanka do Berlinskog kongresa 1804-1878. [The history of the Serbian people, book five, tome one: From the first uprising to the Berlin congress, 1804-1878.] Beograd: Srpska književna zadruga, pp.7-158.

31. Milićević, M.Đ. (ed.) (2001) Knez Miloš priča o sebi. [Prince Miloš talks about himself.] Beograd: Čigoja štampa.

32. Karadžić, V.S. (1828) Miloš Obrenović, Knjaz Serbiji; ili Građa za Srpsku Istoriju našega vremena. [Miloš Obrenović, the Knjaz of Serbia; or Materials for the Serbian History of our time.] Budim: Štamparija kraljevskog universiteta Peštanskoga.

33. Milutinović-Sarajlija, S. (1888) Istorija Srbije od početka 1813e do konca 1815e godine. [The history of Serbia from the beginning of 1813 to the end of 1815.] Beograd: Štamparija Kraljevine Srbije.

34. Kia, M. (2008) The Ottoman Empire. Westport: Greenwood Press.

35. Petrović, J. (1930) Okućje ili zaštita zemljoradničkog minimuma. [Okućje or the protection of the agrarian minimum.] Beograd: Privredni Pregled.

36. Gavrilović, M. (1912) Miloš Obrenović, knjiga treća (1827-1835). [Miloš Obrenović, book three (1827-1835).] Beograd: Davidović.

37. Ljušić, R. (2004) Kneževina Srbija 1830-1839. [The Principality of Serbia in 1830-1839.] Beograd: Zavod za udžbenike i nastavna sredstva.

38. Petrović, V.J. and N. J. (1884) Građa za istoriju Kraljevine Srbije: Vreme prve vlade Kneza Miloša Obrenovića, knjiga druga - od 1821. do 1823. godine. [Materials for the history of the Kingdom of Serbia: The period of the first reign of Prince Miloš Obrenović, book two - 1821 to 1823.] Beograd: Srpska državna štamparija. 
39. Gnjatović, D. (2013) Privilegovana agrarna banka: Prilog istoriji poljoprivrednog kredita Srbije 1836-1947. [The Privileged Agrarian Bank: A contribution to the history of agrarian credit in Serbia 18361947.] Beograd: Udruženje banaka Srbije.

40. Vukosavljević, S. V. (2012) Istorija seljačkog društva I: Organizovanje seljačke zemljišne svojine. [The history of peasant society I: The organising of peasant land property.] Beograd: Službeni glasnik.

41. Gavrilović, M. (1908) Miloš Obrenović, knjiga prva (1813-1820). [Miloš Obrenović, book one (1813-1820).] Beograd: Davidović.

42. Marković, R. (1954) (ed.) Knjažeska kancelarija - knjiga druga: Kragujevačka nahija 1815-1839, sveska prva, 1815-1827. [The Prince's Chancellary - book two: The Kragujevac nahia 1815-1839, tome one, 1815-1827.] Beograd: Državna Arhiva N. R. Srbije.

43. Kunibert, B.S. (1901) Srpski ustanak i prva vladavina Miloša Obrenovića (1804-1850). [The Serbian uprising and the first reign of Miloš Obrenović (1804-1850).] Beograd: Zadužbina Ilije M. Kolarca.

44. Jelavich, B. (2004) Russia's Balkan Entanglements, 1806-1914. Cambridge - New York - Melbourne: Cambridge University Press.

45. Peruničić, B. (1964) Beogradski sud 1819-1839. [The Belgrade court in 1819-1839.] Beograd: Istorijski arhiv Beograda.

46. Quataert, D. (2005) The Ottoman Empire, 1700-1922. New York: Cambridge University Press.

47. Zbornik zakona i uredaba u Knjažestvu Srbiji, u dosadanjim zbornicima neštampanih a izdanih od 2. Februara 1835. do 23. Oktobra 1875. god. [The collection of laws and regulations of the Principality of Serbia, not printed in the collections so far, and promulgated from February 2nd 1835 to October 23rd 1875.] (1877), XXX.

48. Bujuklić, Ž. (2013) 'Doctrinal Reception of European (Roman) Law Tradition In Post-Ottoman Serbia, The Annals of the Faculty of Law in Belgrade - Belgrade Law Review, 3, pp. 101-118.

49. Janković, D. (1985) 'Predistorija Sretenjskog ustava i neke napomene u vezi s njim' [The prehistory of the Sretenje Constitution and some remarks regarding it], in Marković, R. (ed.) 150 godina od donošenja Sretenjskog ustava. [150 years of the Sretenje Constitution.] Kragujevac: Centar za marskističko obrazovanje Univerziteta "Svetozar Marković" u Kragujevcu, pp. 9-20.

50. Obrenović, M. (1834) Slovo srbskoga Knjaza Miloša Teodorovića Obrenovića čitano skupštini naroda srbskoga log Fevruarija 1834. u Kragujevcu. [The address of the Serbian Knjaz Miloš Teodorović Obrenović read to the Assembly of the Serbian people on the 1st of February 1834 in Kragujevac.] Kragujevac: Knjažesko-Srbska Knjigopečatnja.

51. Vulović, D. (1953) (ed.) Knjažeska kancelarija - knjiga prva: Nahija Požeška 1815-1839. [The Prince’s Chancellary — book one: The Požega nahia 1815-1839.] Beograd: Državna arhiva N. R. Srbije.

52. Jovanović, S. (1991) 'Knez Miloš i seljačko pitanje' [Prince Miloš and the peasant question], in: Sabrana dela: Iz istorije i književnosti I. [Collected works: On history and literature I.] Beograd: BIGZ Jugoslavijapublik - SKZ, pp.67-79.

53. Jovičić, M. (1985) 'Ustav Knjažestva Serbije od 1835 ("Sretenjski ustav”) i njegovo mesto u svetu savremene ustavnosti' [The Constitution of the Principality of Serbia of 1835 ("The Sretenje Constitution") and its place in the world of modern constitutionalism], in Marković, R. (ed.) 150 godina od donošenja Sretenjskog ustava. [150 years of the Sretenje Constitution.] Kragujevac: Centar za marskističko obrazovanje Univerziteta "Svetozar Marković" u Kragujevcu, pp. 83-107.

54. Popović, D. M. (2004) 'Sretenjski ustav — oruđe vladavine i vesnik slobode' [The Sretenje Constitution - an instrument of government and herald of freedom], in Mitrović, V. (ed.) Ustav Knjažestva Serbije: 1835 (fototipsko izdanje). [The Constitution of the Principality of Serbia: 1835 (facsimile edition)] Beograd: Arhiv Srbije, pp. 73-78.

55. Avramović, S. (2010) 'Sretenjski ustav - 175 godina posle’ [The Sretenje Constitution -175 years later], Anali Pravnog fakulteta u Beogradu, 1, pp.36-65.

56. Guzina R. (1974) 'Regulisanje svojinskih odnosa u Srbiji XIX veka na bazi običajnog prava' [The regulation of property relations in 19th century Serbia on the basis of customary law], in Čubrilović V. (ed.) Običajno pravo i samouprave na Balkanu i u susednim zemljama. [Customary law and self-administration in the Balkans and neighbouring countries.] Beograd: SANU, pp.455-466.

57. Čalić, M.-Ż. (2004) Socijalna istorija Srbije 1815-1941: Usporeni napredak u industrijalizaciji. [The social history of Serbia in 1815-1941: A slow advance in industrialisation.] Beograd: Clio.

58. Zbornik zakona i uredaba i uredbeni ukaza izdani u Knjažestvu Srbskom, od Aprila 1840. godine do konca Dekemvra 1844. $g$. [The collection of laws and regulations and regulatory decrees promulgated in the Principality of Serbia from April 1840 to the end of December 1844.] (1840), I. 
59. Shaw, S. J. and E. K. (1977) History of the Ottoman Empire and Modern Turkey, volume II: Reform, Revolution, and Republic - The Rise of Modern Turkey 1808-1975. Cambridge - New York - Melbourne: Cambridge University Press.

60. Karpat, K.H. (2002) 'The Land Regime, Social Structure and Modernization in the Ottoman Empire', in Studies on Ottoman Social and Political History: Selected Articles and Essays. Leiden — Boston — Köln: Brill.

61. Zbornik zakona i uredaba i uredbeni ukaza izdani u Knjažestvu Srbskom, od Aprila 1840. godine do konca Dekemvra 1844. g. [The collection of laws and regulations and regulatory decrees promulgated in the Principality of Serbia from April 1840 to the end of December 1844.] (1845), II.

62. Guzina R. (1970) 'Prilog istoriji razvitka svojinskih odnosa u Srbiji u 19. veku' [A contribution to the history of the development of property relations in 19th century Serbia], Anali Pravnog fakulteta $u$ Beogradu, 1-2, pp. 27-44.

For citation: Kršljanin N. The land reform of the 1830s in Serbia: the impact of the shattering of the Ottoman property system. Vestnik SPbSU. Law, 2017, vol.8, issue 1, pp.26-41. DOI: 10.21638/11701/ spbu14.2017.102.

Received 17.07.2016

Accepted 01.12.2016. 